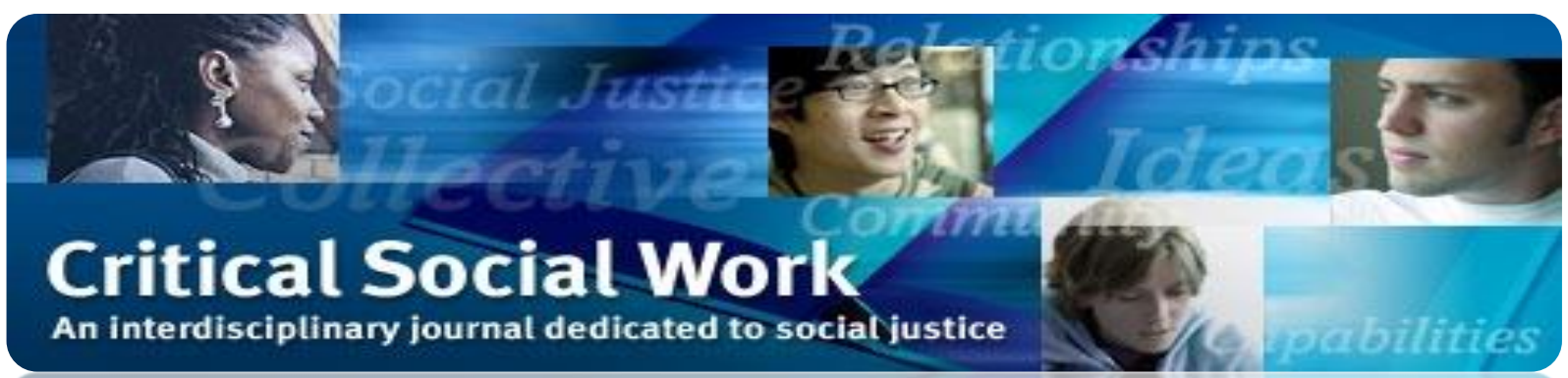

Critical Social Work

School of Social Work

University of Windsor

167 Ferry Street

Windsor, Ontario N9A 0C5

Email: cswedit@uwindsor.ca

Publication details, including instructions for authors and subscription information can be found at: http://uwindsor.ca/criticalsocialwork

Link to article:

http://www1.uwindsor.ca/criticalsocialwork/ReplyVampireArticle

Critical Social Work, 2016 Vol. 17, No. 2 


\title{
Reply to "Do We Always Practice What We Preach? Real Vampires' Fears of Coming Out of the Coffin to Social Workers and Helping Professionals."
}

\section{Critical Social Work 17(2)}

\author{
Joseph P. Laycock
}

Texas State University

\begin{abstract}
Author Note
Joseph P. Laycock is the author of Vampires Today: The Truth About Modern Vampires (Praeger, 2009).
\end{abstract}

\begin{abstract}
This reply analyzes criticism of the article "Do We Always Practice What We Preach? Real Vampires' Fears of Coming Out of the Coffin to Social Workers and Helping Professionals" published in Critical Social Work (2015), 16(1) by DJ Williams and Emily E. Prior. That article was widely publicized and received a seemingly disproportionate amount of criticism from both religious and secular voices. This reply applies Peter Berger's notion of anomie to suggest that critics of the article felt threatened by the implications of tolerating emerging identity claims, such as those made by self-identified vampires. By attacking Williams and Prior as unreasonable, these critics suggest that an individual's ontological status is taken-for-granted rather than socially constructed. Paradoxically, their protests also suggest an awareness that ontological status actually is socially constructed and that helping professionals, such as Williams and Prior, are imbued with cultural authority that can alter the established order. This reply suggests that the ontological threat presented by helping professionals is what is actually at stake in these critiques. Critiquing the article appears to be not only a call for the continued medicalization of self-identified vampires as deviant, but more importantly a strategy of repressing the realization that norms are socially constructed and therefore susceptible to change.
\end{abstract}

Keywords: vampires, identity, sociology of knowledge, ontology, anomie 
Laycock

Within my own discipline of religious studies, I have been doing ethnography with the so-called "vampire community" since 2007. While I was not surprised to see DJ Williams and Emily E. Prior's article in Critical Social Work (CSW) (2015), 16(1), I was surprised by the backlash it received in the summer of 2015. Both religious and secular voices suggested that Williams and Prior were irresponsibly encouraging a delusion. I found this reaction especially strange because I received no such censure for my own work on this community. I think this discrepancy was not caused by anything Williams and Prior said, but rather how the public perceives our respective disciplines. It is assumed (wrongly) that religious studies deal exclusively with ideas that are private, often strange, and completely subjective. Meanwhile, the helping professions are looked to as gatekeepers of what is deviant and what is "healthy." When Williams and Prior suggested that helping professionals not ridicule self-identified vampires in order to maintain the therapeutic alliance, they lent legitimacy to the identity claims of vampires that a religious studies professor never could. I believe it was this modification to the socially constructed boundaries of deviance that some people found so upsetting. The backlash against Williams and Prior's article is sociologically interesting not only because it shows how the public perceives helping professionals as the arbitrators of which identity claims are legitimate, but because it demonstrates an awareness that our cultural repertoire of legitimate identity claims is socially constructed and the product of discourse. Thus, even as critics attack Williams and Prior's article for treating "crazy" people as if they were sane, paradoxically they betray an understanding that this distinction was always an arbitrary one.

Although the so called "real vampire community" has existed in one form or another at least since the 1970s, it has become far more public in recent years owing to an increased Internet presence, news specials and documentaries, and several experiments in "reality television" featuring self-identified vampires. While the public's encounter with this community has been primarily through sensationalized media, in my experience, the majority of selfidentified vampires are not driven by a desire for attention; many of them feel strongly that they must feed on either the blood or "subtle energy" of other people in order to maintain their physical, mental, and spiritual health (Laycock 2009, 2010). While vampires disagree about whether this perceived condition constitutes some sort of "disorder," they frequently frame their identities in terms of wellness.

When I first began studying vampires, the assumption in my field was that this community was a new religious movement (NRM), that they were organized in a way similar to religious groups, and that the focus of this community was a set of shared beliefs and practices. However, I found that relatively few vampires consider vampirism to be a religion. Many have some other religious identity in addition to their identity as a vampire. Instead, my interview subjects expressed that vampires are a different kind of person with different needs and proclivities (Laycock 2009, 2010). Many compared being a vampire to a sexual orientation in the sense that they felt they were born with this identity.

Society does not currently have a suitable framework for categorizing these kinds of ontological identity claims. Because of this, identifying as a vampire is most often interpreted as either a religious conviction or a mental illness (Laycock 2009, 2010). There is no established third category through which outsiders can think about them. In 2009, I hypothesized that there would come a time when medical and helping professionals would discover this community and 
Laycock

begin formulating an understanding of what their identity claims mean (Laycock 2009, pp. 164166). Now that time has apparently come. In addition to Williams and Prior's article that appeared in CSW (2015), I received an article for peer-review in a medical journal describing an encounter with a hospital patient who identifies as a vampire (The journal decided not to publish the article). That same summer, a third article appeared, Vampires amongst us, even in the ER. It was written by Reddy (2015), an ER doctor, and it described her encounter with a self-described vampire. These encounters between helping professionals and vampires are contributing to an emerging public discourse about vampires and their identity claims. It remains to be seen what role helping professionals will play in how the public interprets these claims.

Williams and Prior's attempt to humanize vampires created a media tempest. The article was discussed in such places as Newsweek (Kutner 2015), Men's Health (Taylor 2015), and MTV.com (McKenna 2015). There was also a substantial backlash in the form of both editorials and hate mail directed at the authors. Some of Williams and Prior's critics took aim at their data even though their approach was primarily qualitative and concerned ethics. (Notably, critics apparently did not feel that quantitative data was necessary to assert that vampires are mentally ill, only that they might not be.) However, the majority of critics simply seemed offended that the authors were taking vampires seriously.

Some of this hostility appeared to be simple anti-intellectualism fueled by the American culture wars. For example, one e-mailer informed Williams that he was "JUST ANOTHER LIBERAL IDIOT INFESTING AMERICAN UNIVERSITIES WITH JUNK STUDIES” (D.J. Williams, personal communication, June 16, 2015). However, some of the longer critiques turned into jeremiads about the state of modernity and society's alleged reluctance to deny anyone's identity claims. This reaction was undoubtedly due to timing: Critical Social Work published the article only days after the U.S. Supreme Court's Obergefell v. Hodges decision, which legalized gay marriage across the country. The summer of 2015 was also marked by debates over the identity claims of Caitlyn Jenner (formerly Bruce Jenner), a celebrity and transgender woman who came out in an April 2015 interview on 20/20, and Rachel Dolezal, a professor and activist who identifies as black despite having two white parents. Taken together, the discourse surrounding these events likely caused some people to feel that such taken for granted identity categories as sexual orientation, gender, and race had become unhinged and that the very structures through which we understand the world and ourselves are now sliding into chaos. In an op-ed entitled "The Year We Obsessed Over Identity," Morris (2015) suggests that the rise of Donald Trump represents a conservative backlash against changing attitudes about identity claims.

Within this political environment, Williams and Prior may have made an easy rhetorical target. Several responses to the article frame their approach to vampires alongside the gay rights movement either implicitly or explicitly. In these critiques, vampire identity claims represent an extreme example of a larger trend. As such, they can be attacked as ridiculous without being accused of bigotry, but they can also be used as metonymy for all contested identity claims.

The work of sociologist Peter Berger is helpful for understanding why emerging identity claims are threatening. Berger argued that human beings require a socially constructed framework for understanding the world in order to function. In order to be effective, the 
Laycock

framework must be so authoritative that it seems taken for granted. Berger uses the term anomie to describe conditions when the taken-for-granted status of this structure has been compromised. Anomie, Berger explains, is the "nightmare par excellence" for human beings because it means living in a world without order or purpose (Berger, 1967, p. 22). Let us consider both a religious and a secular critique of the article. I argue that both portray a fear of anomie, even as they critique Williams and Prior as deluded or unreasonable.

An editorial in the traditionalist Catholic newspaper The Remnant writes:

If I decide to start identifying as a werewolf, you'd better get ready to defend my inalienable right to be treated as such. After all, this is America! I can demand my own special werewolf public restrooms, Congress will enact new laws forcing barbers to give me the full-body werewolf treatment, and you WILL bake me a were-cake!

Where will it stop? Hell, I guess. Buy [sic] if we continue down Lunacy Lane here, I wonder how we will ultimately ascertain who is mentally ill in our society and who is not; who needs treatment and who does not; who's dangerous and who isn't; who is, well, quite frankly, nuts and who's sane. Or, will it even matter anymore, now that the inmates are clearly running the asylum. (Matt, 2015, para. 1-2)

This passage begins as a satire of political correctness but it ends with a vision of anomie: Vampires are threatening because they cause taken for granted categories, such as sane and insane to appear factitious and arbitrary. There is also a paradox inherent in this critique: The proposition that vampires are not sane is presented as an objective fact, but if sane and insane were truly objective categories, then vampires could never have presented a challenge to these boundaries in the first place. What this author is really engaged in is reinforcing an illusion of objectivity in order to stave off anomie.

Ethicist Matthew Beard (2015) published an editorial in The Guardian entitled, "OK, so you think you're a vampire. Whose job is it to tell you you're not?" Beard appears to assume $a$ priori that people should not identify as vampires. Whether this is a problem for the vampires themselves, society in general, or both, is not explicitly stated. Next, Beard takes issue with Williams and Prior's explanation that being a vampire is an essentialist identity, akin to a sexual orientation. Unlike The Remnant, which is openly hostile toward the gay rights movement, Beard expresses his concern that it is hard to support gay rights while dismissing vampires. He writes:

The reason it is hard is because we lack a coherent, objective framework that builds on an amalgamation of historical, cultural, philosophical, artistic, and scientific accounts of what it means to be a human being, and what it is to live in human community.

Instead, society determines legitimate forms of self-determination or identity on the basis of consensus. If sufficient numbers of people demand recognition, they are rewarded it, but until then, they won't be treated legitimately. (Beard, 2015, para. 10-11)

For Beard, vampires represent the decline of an "objective" value system on which norms should be based. He describes vampires as "the unintended and unwitting victims of years of 
Laycock

value-neutral education" (para. 19). It is difficult to imagine how the sort of amalgamation of influences Beard describes could result in a framework that might be considered "objective" rather than culturally constructed. From the perspective of the sociology of knowledge, it is hard to speak of "objective values" because values themselves are also frequently the product of a consensus. It is also worth noting that Williams and Prior were hardly "value neutral" in suggesting that helping professionals should reserve judgment when encountering people with alternative identity claims.

Beard concludes his essay:

The solution isn't - as the authors of the study argue - to be careful not to proliferate traditional vampire mythology - garlic, stakes, coffins and all the rest - which is likely to lead to microaggressions that could traumatise "real vampires".

Rather, it's to recognise that the quest for self-identity and meaning is one that is best done with some guidance. (2015, para. 25-26)

Whose guidance is Beard advocating? Clearly, not helping professionals, such as Williams and Prior, or a consensus of non-experts. This conclusion seems to be a call for some sort of benevolent hegemony empowered to decide whose identity claims are legitimate and whose are not. However, creating such an authority would certainly cause more ethical problems then it would solve.

I think that the backlash over Williams and Prior's article is not about preserving objectivity, but rather hegemony, especially the rhetorical privilege to medicalize deviance as insanity. Above all, I think these critiques function to repress the critics' own realization that reality is socially constructed. This response is motivated not by malice, but a fear of anomie. For some people, when Williams and Prior suggested that vampires are worthy of regard and empathy, they inadvertently invited this nightmare into the world. For these critics, vampires must be insane so that their world can be sane.

\section{Discussion}

In closing, I would like to suggest that the emergence of new forms of identity is a natural social process resulting from discourse, and that helping professionals ultimately have no power to stop this process. In his book, The Heretical Imperative, Berger (1979) suggested that modernity entails an ever-widening range of identities and lifestyle choices in which fewer dimensions of our personhood can be taken for granted and more must be discovered, defined, or chosen (Heresy comes from the Greek hairesis, "choice"). The Heretical Imperative was written in 1979, but the question of whether one is a normal human being or a vampire can be regarded as the next logical phase of the process Berger describes. In this sense, the identity claims of vampires may have been historically inevitable.

Furthermore, historians such as Foucault (1990) and Ian Hacking (1986) have noted that medical professionals have had a leading role in "inventing" new kinds of people. Foucault 
Laycock

(1990, p. 101) explains how "the homosexual" was invented as a category of person in the nineteenth century and how this new discourse paved the way for the gay rights movement:

There is no question that the appearance in nineteenth-century psychiatry, jurisprudence, and literature of a whole series of discourses on the species and subspecies of homosexuality, inversion, pederasty, and "psychic hermaphrodism" made possible a strong advance of social controls into this area of "perversity"; but it also made possible the formation of a "reverse" discourse: homosexuality began to speak in its own behalf, to demand that its legitimacy or "naturality" be acknowledged, often in the same vocabulary, using the same categories by which it was medically disqualified.

Foucault's analysis suggests that even if Williams and Prior had been openly hostile toward vampires, this would not have mattered in the end. The discourse itself legitimizes new categories of people. Furthermore, by publishing critiques of Williams and Prior, the critics are generating more discourse about vampires, further legitimating the idea that vampires are a distinct identity group. Given all this, I do not think we have a choice about living with selfidentified vampires. This being the case, why should helping professionals delay the conversation about how to interact with them? 
Laycock

\section{References}

Beard, M. (2015, July 30). OK, so you think you're a vampire. Whose job is it to tell you you're not. The Guardian. Retrieved from http://www.theguardian.com/commentisfree/2015/jul/31/ok-so-you-think-youre-avampire-whose-job-is-it-to-tell-you-youre-not

Berger, P. L. (1967). The sacred canopy: Elements of a sociological theory of religion. Garden City, NY: Doubleday.

Berger, P. L. (1979). The heretical imperative: Contemporary possibilities of religious affirmation. Garden City, NY: Anchor Press.

Foucault, M. (1990). The history of sexuality: Vol. 1. An introduction. New York, NY: Vintage Books.

Hacking, I. (1986). Making up people. In T. C. Heller, M, Sosna, \& D. E. Wellbey, (Eds.), Reconstructing individuality: Autonomy, individuality, and the self in Western thought (pp. 223-236). Stanford, CA: Stanford University Press.

Kutner, M. (2015, July 9). Real vampires exist, and they need counseling too. Newsweek. Retrieved from http://www.newsweek.com/real-vampires-exist-and-they-needcounseling-too-351575

Laycock, J. (2009). Vampires today: The truth about modern vampirism. Westport, CT: Praeger.

Laycock, J. (2010). Real vampires as an identity group: Analyzing the causes and effects of an introspective survey by the vampire community. Nova Religion, 14, 4-23. 